\title{
Development of Immovable Property Tax in Latvia
}

\author{
Sandra Štucere* \\ Municipal Revenue Administration of Riga City Council \\ Gunita Mazūre \\ Department of Accounting and Finance, LLU
}

\begin{abstract}
Immovable property tax is one of the national taxes the administration of which is subjected to continuous changes. Frequent amendments to the law "On Immovable Property Tax" (1997) also evidence the mentioned changes. The procedure for tax calculation, tax base, and tax rates has been considerably changed in the course of time. The research provides a discussion on the changes in tax formation, development, and administration in Latvia to understand better the essence of immovable property tax. The research aim was to analyse the development of immovable property tax and the course of reforms for the period of 1998-2012. The research also studies the expected changes in the application of immovable property tax from the year 2013. It is envisaged to transfer the rights to local governments to determine the immovable property tax rates in their administrative territories within the range of $0.2-3 \%$ from 2013 . The research concludes that frequent reforms of immovable property tax have promoted the development of a new, stable, and predictable methodology for the future application of immovable property tax in Latvia. The analysis of revenues from immovable property tax for the period of 2006-2011 is based on the annually growing significance of immovable property tax. The research suggests that immovable property tax is the only tax the revenues of which have increased within the period of 2009-2011 and the largest revenues from immovable property tax are collected in Riga City municipality comprising $53 \%$ of the total revenues from immovable property tax collected in Latvia.
\end{abstract}

Key words: Immovable property tax reform, tax structure, analysis of revenues.

\section{Introduction}

In Latvia, many discussions have been recently held on the necessity to change the procedure for the application of immovable property tax. Reforms and frequent legislative amendments related with immovable property tax have complicated the application of immovable property tax in Latvia. Hence, relatively little attention has been paid to issues of immovable property tax formation and development.

Aizsilnieks (1968) and Urtāns (2003) have viewed historical aspects of immovable property tax; yet, they have viewed tax as a history of the national economy. In Latvia, immovable property tax policy, aspects of tax application and improvement have been studied by Kavale (1998), Sīpola (2001), Lukašina (2004), Zvejnieks (2006), Vītola (2006), Sproǵe (2007), Kodoliṇa-Miglāne (2007), Ketners (2009), Vanags (2010), Guḷāns (2010) and others.

Topicality and choice of the research theme is based on the fact that there are no scientific publications among relatively few publications on immovable property tax issues dwelling upon the studies of immovable property tax development and reforms in Latvia for the period of 1998-2012.

The research is based on the hypothesis that frequent reforms of immovable property tax have promoted the development of a new, stable, and predictable methodology for the future application of immovable property tax in Latvia.

To verify the hypothesis, the aim was set: to analyse the development of immovable property tax and the course of reforms for the period of 1998-2012 as well as the expected changes in 2013.

The following tasks were advanced to achieve the set aim: 1) to study the application and reforms of immovable property tax in Latvia; 2) to compare tax revenues, structure, and the proportion and position of immovable property tax in total tax revenues of Latvia; and 3) to compare the breakdown of immovable property tax revenues by the largest cities of Latvia and to analyse the dynamics of immovable property tax revenues in Riga city. 


\section{Materials and Methods}

Historical approach method, monographic descriptive method and methods of economic and statistical data analysis were used for the research purpose.

Legal and regulatory enactments and documents of the Republic of Latvia related with immovable property tax were used to analyse legislative base regulating immovable property tax. In addition, data of the Ministry of Finance of the Republic of Latvia and the State Revenue Service were used to analyse and to compare revenues from immovable property tax for the period of 2006-2011, as well as data of Riga City municipality on the budget performance were used to analyse the dynamics of Riga city revenues from immovable property tax for the period of 2006-2011.

\section{Results and Discussion}

Immovable property tax is one of the national taxes the administration of which is subjected to continuous changes. Frequent amendments to the law "On Immovable Property Tax" (Par nekustamā ..., 1997) also evidence the mentioned changes. Not only the enumeration of taxable items but also the procedure for tax calculation, tax base, tax rates, and tax reliefs has been considerably changed in the course of time. Therefore, not always taxpayers have a clear understanding on the amount of tax to be paid and on the principles for its calculation.

Immovable property tax is a significant source of budget revenues for local governments. Unlike other taxes, a local government calculates immovable property tax for real estate located in its territory. In contrast, Section 8, Paragraph 4 of the law "On Immovable Property Tax" (Par nekustamā ..., 1997) prescribes that the State Revenue Service performs the control function for the application of the mentioned tax, namely, it checks the compliance of calculation, collection, and accounting for immovable property tax done by the local government with the norms of legal and regulatory enactments.

Local governments play the basic role in the administration of immovable property tax, since they ensure basic processes for tax administration: registration of taxpayers, tax calculation, information of taxpayers on the amount of payable tax, accounting for tax revenues, collection of tax debts, and consultation of taxpayers.

\section{Process of immovable property tax reforms in Latvia}

History on the formation, development, and administration of immovable property tax in Latvia is described to provide a better understanding on its essence.

According to the ideas expressed in Urtāns (2003) and Aizsilnieks (1968) studies, already in the 12th century the house-owners in Riga paid a tax on immovable property, which was calculated by the value of owned house or building. In addition to immovable property tax, the town council gained revenues from the land tax imposed on the use of town buildings, landed estates, and land areas for storage of goods. The Town Council as the highest finance and tax institution imposed and collected these taxes. Riga City Tax Department was established at the end of the 18th century, and inspectors from the Tax Department strictly listed and supervised all the taxpayers. After the proclamation of the Republic of Latvia, paying of a lump-sum immovable property tax was determined in the towns. The tax rate was $3 \%$ of the real estate value and it had been changed several times over the years. The immovable property tax provided the largest revenues in municipal budgets, and it shall be noted that already at that time tax reliefs were envisaged for real estate belonging to the state, municipality, or charity organisations. Tax on immovable property was also collected during the Soviet and German occupation; yet, the only difference was in the name of the tax.

In Latvia, a new tax system became effective from 1 January 1991. In December 1990, laws "On Property Tax" (Par īpašuma ..., 1990) and "On Land Tax" (Par zemes ..., 1990) were passed and they became effective on 1 January 1991.

The law "On Land Tax" (1990) was aimed to raise interest of land users and municipalities in better management of land located in their territories. The law identified taxpayers, land areas, tax rates, tax reliefs, and procedure for tax payment as well as granted rights to municipalities to increase or decrease tax rates even up to 3 times. The land tax was levied upon land areas which by the governmental or municipal decision were transferred to natural and legal entities for use or were their property. From 1997, the land tax was calculated at a rate of $1.5 \%$ of the land cadastral value or the land cadastral base value calculated by a municipality. Municipalities calculated the land cadastral base value by the land cadastral sample value considering the aim for the 
land use and belonging to a particular land value zone for those land items that lacked the identified cadastral value (Grozījumi likumā „Par zemes ...”, 1997).

The development of national economy and business required the necessity to reform and change the existing tax system, thus approximating it to the European Union tax policy principles. Significant changes in the tax system of Latvia occurred between 1994 and 1998 when almost all tax laws being in force were replaced with new laws, which specified or abolished the existing taxes and introduced several new taxes instead.

From 1 January 1998, the law “On Land Tax” (Par zemes ..., 1990) became invalid and it was replaced with the law "On Immovable Property Tax" (Par nekustamā ..., 1997).

The draft law "On Immovable Property Tax" was elaborated and submitted to the Parliament for the review already in 1995; however, according to the government acknowledgement, the law may not become effective up to the introduction and verification in practice of the methodology for determination of tax base. The State Land Service needed time to establish a corresponding informative and technical base for the introduction of immovable property mass cadastral valuation system, to ensure the necessary software, and to train employees.

The process of immovable property tax reform from 1998 to 2012 is outlined in Table 1.

Discussing and analysing the process of immovable property tax reform and continuous amendments to the law, it is essential to remember the aim set for the tax reform - to ensure maximum simple and fair taxation of immovable property through the principle of neutrality, i.e. low tax rate, wide range of taxpayers, and minimum tax reliefs. In addition, the aim of the law is to ensure stable and foreseeable municipal budget revenues from this tax (Fililipoviča \& Lāce, 2006).

1 January 1998 is regarded as the beginning of immovable property tax reform when the law "On Immovable Property Tax" became effective. Initially, the law envisaged the imposition of the tax only on land with the application of a tax rate of $1.5 \%$ and cadastral value serving as the tax base. The law "On Property Tax" (Par îpašuma ..., 1990) continued to operate in parallel, the tax rate ranged between $0.5 \%$ and $4 \%$ depending on the property book or stock-taking value. Taxpayers themselves calculated the property tax by submitting a declaration on the expected value of taxable property and the amount of tax to be paid in the respective year to the State Inspection of Finance, later the State Revenue Service. In 1998, a lowering coefficient of $0.8 \%$ was applied to the property tax to promote business. In 1999, fixed assets were excluded from the taxable items to enhance procurement and renovation of production equipment (Grozījumi likumā „Par īpašuma ...", 1997).

It was envisaged to impose the immovable property tax at the rate of $1 \%$ both on land and buildings according to their cadastral value from 2000. Tax calculation by the cadastral value of buildings was suspended until 1 January 2007. The suspension was based on both the insufficient capacity of the State Land Service and financing allocated for the process of cadastral valuation of immovable property as well as the expected decrease of revenues from immovable property tax in municipal budgets.

Starting from 2000, municipalities were increasingly involved in the implementation of tax administration functions. On 1 January 2000, the law "On Property Tax" (1990) became invalid and terms on taxation of buildings and constructions were included into the transitional provisions of the law “On Immovable Property Tax" by 31 December 2006 (Grozījumi likumā „Par nekustamā ...”, 1999). By 1 January 2000, the State Revenue Service had to hand information being at its disposal on taxpayers and items taxable with immovable property tax to the municipalities so the municipalities had accounting on those payers of immovable property tax who were paying tax on buildings and constructions.

Therefore, similar to land, buildings and constructions were taxed at the rate of $1.5 \%$ from 2000 to 2006. Yet, the book or stock-taking value and not the cadastral value served as the tax base. A considerable tax relief was introduced from 2001 to attract investment and reduce tax burden in business sector, namely, immovable property tax is not imposed upon buildings erected or reconstructed for the performance of economic activities - for one year counting from the next month after its transfer for exploitation, and this provision is still being in force (Grozìjumi likumā „Par nekustamā ...", 2000).

Starting from 2007, constructions were excluded from the taxable items and the calculation of immovable property tax on buildings was started applying the cadastral value as the tax base. 
The process of immovable property tax reform from 1998 to 2012

\begin{tabular}{|c|c|c|c|c|}
\hline \multirow{2}{*}{ Year } & \multicolumn{2}{|r|}{ Rate } & \multirow{2}{*}{ Item } & \multirow{2}{*}{ Base } \\
\hline & land & buildings & & \\
\hline 1998 & \multirow{2}{*}{$1.5 \%$} & $\begin{array}{c}\text { Buildings and } \\
\text { constructions, fixed assets } \\
-0.5 \%-4 \% * \\
\end{array}$ & $\begin{array}{l}\text { Land, buildings, } \\
\text { constructions, } \\
\text { fixed assets }\end{array}$ & \multirow{3}{*}{$\begin{array}{c}\text { for buildings, } \\
\text { constructions, } \\
\text { fixed assets - } \\
\text { book value or } \\
\text { stock-taking } \\
\text { value }\end{array}$} \\
\hline 1999 & & $\begin{array}{c}\text { Buildings and } \\
\text { constructions - } \\
0.5 \%-4 \%\end{array}$ & \multirow{2}{*}{$\begin{array}{l}\text { Land, buildings, } \\
\text { constructions }\end{array}$} & \\
\hline $\begin{array}{l}2000- \\
2006\end{array}$ & \multicolumn{2}{|r|}{$1.5 \%$} & & \\
\hline 2007 & \multicolumn{2}{|r|}{$1.5 \%$} & \multirow[b]{2}{*}{ Land, buildings } & \multirow{5}{*}{ Cadastral value } \\
\hline $\begin{array}{l}2008- \\
2009 \\
\end{array}$ & \multicolumn{2}{|r|}{$1 \% * *$} & & \\
\hline 2010 & \multirow{2}{*}{$\begin{array}{l}\text { Land }-1.5 \% * * \\
\text { Non-cultivated } \\
\text { agricultural area } \\
\quad-3 \% * * *\end{array}$} & $\begin{array}{c}\text { Buildings }-1.5 \% * * \\
\text { Engineering } \\
\text { constructions }-1.5 \% \\
\text { Residential buildings - } \\
0.1 \%-0.3 \% \\
\end{array}$ & \multirow{3}{*}{$\begin{array}{l}\text { Land, buildings, } \\
\text { engineering } \\
\text { constructions, } \\
\text { residential } \\
\text { buildings }\end{array}$} & \\
\hline 2011 & & $\begin{array}{c}\text { Buildings }-1.5 \% * * \\
\text { Engineering } \\
\text { constructions }-1.5 \% \\
\text { Residential buildings - } \\
0.2 \%-0.6 \%\end{array}$ & & \\
\hline 2012 & $\begin{array}{c}\text { Non-cultivated } \\
\text { agricultural area } \\
-3 \% * * * \\
\text { Land - } \\
1.5 \% * * * *\end{array}$ & $\begin{array}{c}\text { Engineering } \\
\text { constructions }-1.5 \% \\
\text { Residential buildings - } \\
0.2 \%-0.6 \% \\
\text { Buildings }-1.5 \% * * * *\end{array}$ & & \\
\hline
\end{tabular}

$*_{-}$- in 1998 , multiplied by the coefficient 0.8 ; * - the amount of immovable property tax may not exceed $25 \%$ compared with the previous year; $* * *$ - excluding land, the area of which does not exceed one hectare or which has restrictions for agricultural activities stated by regulatory enactments; **** - Binding Regulations issued by every municipality prescribe procedure for the calculation of immovable property tax.

Source: based on Grozījumi likumā „Par īpašuma nodokli” (1997) and Grozījumi likumā „Par nekustamā īpašuma nodokli” $(1999,2009,2011)$.

The next stage of immovable property tax reform pertains to the year 2005 when the State Land Service started to update the zoning of land values. A significant increase in immovable property tax was expected from January 2008, since several Cabinet Regulations, which would envisage updating of the base of immovable property cadastral values, had to be passed in 2007 consistent with the "National Real Estate Cadastre Law" (Nekustamā īpašuma ..., 2005).

Calculations provided by the State Land Service showed that the average increase in cadastral value from the year 2008 would be for:

- agricultural land - 2 times;
- land used for construction of individual residential buildings - 5.6 times;

- land used for construction of units for commercial activities -5.5 times;

- land used for construction of production units 5.1 times.

In turn, a slight increase in cadastral value was expected for taxable buildings (1.5 times for commercial buildings and 1.2 times for industrial buildings on average), since the value base of buildings was updated already in 2006 (Informatīvais ziņojums ..., 2007).

Starting from 2008, the immovable property tax rate was reduced down to $1 \%$ and the limitation 
for the increase of tax in the amount of $25 \%$ was determined to avert the increase of immovable property tax burden.

The next stage of immovable property tax reform pertains to the expansion of immovable property tax base. Extensive discussions on taxation of housing fund have been hold in the society of Latvia for a long time. On 1 December 2009, amendments to the law "On Immovable Property Tax" were adopted after long discussions and they came into force on 1 January 2010. The amendments stipulated that residential buildings are taxed at a progressive tax rate within a range from $0.1 \%$ to $0.3 \%$. Immovable property tax rate was also changed for land and non-residential buildings to $1.5 \%$ of cadastral value (instead of the previous $1 \%$ ), and it was prescribed that immovable property tax should be imposed upon engineering constructions at a rate of $1.5 \%$ of cadastral value of the immovable property, and upon uncultivated agricultural land - at a rate of $3 \%$ of cadastral value.

Starting from 2011, immovable property tax rate is doubled at a rate of $0.2-0.6 \%$ of cadastral value for residential buildings; this tax rate is effective also in 2012.

An essential novelty in the administration process of immovable property tax is introduced from 2012. Municipalities are eligible to issue Binding Regulations, which are adopted consistent with Section 46 of the law "On Municipalities" (Par pašvaldībām, 2011). The Binding Regulations prescribe the rights to apply the increase in tax rate limitation in 2012 or retain the amount of tax at the rate of 2011 as well as to state whether the immovable property tax is imposed upon auxiliary buildings and environment degrading constructions (Grozījumi likumā „Par nekustamā ...”, 2011).

The analysis of Binding Regulations adopted in the largest cities and towns of Latvia (Par nekustamā īpašuma nodokḷa piemērošanu Daugavpils..., 2012; Nekustamā īpašuma nodokḷa..., 2012; Par nekustamā īpašuma nodokḷa aprēķināšanu..., 2012; Par nekustamā īpašuma nodokli Jūrmalā, 2012; Par nekustamā īpašuma nodokli Rīgā, 2012; Kārtība, kādā tiek..., 2012) leads to the conclusion that the limitation for the increase in immovable property tax is retained in these cities and towns - in 2012, the amount of immovable property tax may not exceed the amount of tax calculated for the previous taxation year by more than $25 \%$, as well as the tax is not imposed upon auxiliary premises of residential buildings.
Starting from 2013, the government of Latvia has envisaged considerable changes in the sphere of immovable property tax. It is anticipated to confer the rights to the municipalities to determine immovable property tax rates within a range from $0.2 \%$ to $3 \%$. Therefore, each municipality shall issue Binding Regulations prescribing the procedure for setting of immovable property tax rates and tax administration. Binding Regulations shall be issued prior to 1 July 2012. A significant novelty is that municipalities are obliged to observe several principles setting the immovable property tax rates:

1) principle of equitable grouping under which taxpayers or taxable items are grouped consistent with equitable criteria;

2) principle of efficiency under which a municipality proportionates tax administration expenses with tax revenues;

3) principle of responsible budget planning under which a municipality balances its responsibilities with the resources necessary for the performance of responsibilities;

4) principle of predictability and stability under which tax rates are duly set for at least a two-year period if the increase or decrease in immovable property base value is less than $20 \%$ comparing the base values in the taxation year and the pretaxation year;

5) principle of business support under which a municipality applies the tax rate as means to increase the competitiveness of businesses or certain sectors of business operating in its territory;

6) principle of social responsibility under which a municipality reckons on the impact of tax rate on the groups of socially less-protected and needy population as well as ability of population to pay taxes;

7) principle of the territorial development and arrangement under which a municipality applies the tax rate to promote the development and arrangement of its territory (LR Finanšu ministrija, 2012).

Hence, the continuous changes in and reforms of immovable property tax speak on its topicality. Therefore, the latest adopted amendments to the law may be considered only as temporary solution, since the government is continuing discussions on the improvement of possibilities of the immovable property tax. Therefore it is possible to assert that the immovable property tax reform is being continued. The continuous changes in immovable property tax 
have enhanced the introduction of a new predictable and stable process for setting immovable property tax rates in Latvia from 2013.

\section{Assessment of the share of immovable property tax in general government- consolidated budget tax revenues of Latvia}

The analysis of the role and share of immovable property tax in total tax revenues of Latvia is based on the annual increasing topicality of immovable property tax.

Tax revenues and tax structure in Latvia for the period of 2006-2011 are outlined in Table 2. The analysis of general governmental consolidated budget tax revenues for the period of 2006-2008 shows that tax revenues have annually increased, thus reaching LVL 5009.5 million in 2008, which has been the highest indicator for the entire analysed period. Tax revenues have considerably decreased in 2009 with the onset of the economic crisis in Latvia, thus reaching the lowest indicator of LVL 3506.5 million in 2010, which is LVL 1503 million or $30 \%$ less compared with 2008. The decrease in tax amount is due to the rapid decline in internal consumption, wages, salaries, and corporate profit, and the increase in unemployment, shadow economy, and structural changes in tax base.

In 2009, corporate income tax (CIT) tax experienced one of the most considerable declines, which was by LVL 305.9 million or $60.8 \%$ less compared with 2008. The decrease relates to a significant reduction of corporate profit. The economic slowdown and decrease in wages and employment affected the decline in the amount of bulky state social mandatory insurance contributions and personal income tax. Irrespective of the implemented changes in the administration of personal income tax, in 2010 (reduction in the untaxed minimum and

Tax structure and tax revenues of Latvia for the period of 2006-2011

Table 2

\begin{tabular}{|c|c|c|c|c|c|c|c|c|c|}
\hline \multirow[b]{2}{*}{ Year } & \multirow[b]{2}{*}{ Indicator } & \multicolumn{8}{|c|}{ Type of tax } \\
\hline & & SSMIC & VAT & PIT & LGT & CIT & IPT & $\begin{array}{l}\text { Other } \\
\text { taxes }\end{array}$ & $\begin{array}{c}\text { Tax } \\
\text { revenues, } \\
\text { total }\end{array}$ \\
\hline \multirow{2}{*}{2006} & $\begin{array}{l}\text { Revenues, } \\
\text { LVL million }\end{array}$ & 1000.21 & 930.5 & 657.2 & 366.2 & 253.8 & 66.4 & 66.4 & 3340.7 \\
\hline & Share, $\%$ & 29.9 & 27.8 & 19.7 & 11 & 7.6 & 2 & 2 & 100 \\
\hline \multirow[t]{2}{*}{2007} & $\begin{array}{l}\text { Revenues, } \\
\text { LVL million }\end{array}$ & 1377.4 & 1202.9 & 888 & 448.1 & 399.8 & 74.2 & 84.9 & 4475.3 \\
\hline & Share, $\%$ & 30.8 & 26.9 & 19.8 & 10 & 8.9 & 1.7 & 1.9 & 100 \\
\hline \multirow[t]{2}{*}{2008} & $\begin{array}{l}\text { Revenues, } \\
\text { LVL million }\end{array}$ & 1667.5 & 1117.2 & 1035.4 & 540.9 & 503.1 & 70.7 & 74.7 & 5009.5 \\
\hline & Share, $\%$ & 33.3 & 22.3 & 20.7 & 10.8 & 10 & 1.4 & 1.5 & 100 \\
\hline \multirow[t]{2}{*}{2009} & $\begin{array}{l}\text { Revenues, } \\
\text { LVL million }\end{array}$ & 1330.3 & 798.4 & 729.4 & 504.1 & 197.2 & 73.1 & 46.2 & 3678.7 \\
\hline & Share, $\%$ & 36.2 & 21.7 & 19.8 & 13.6 & 5.4 & 2 & 1.3 & 100 \\
\hline \multirow[t]{2}{*}{2010} & $\begin{array}{l}\text { Revenues, } \\
\text { LVL million }\end{array}$ & 1157.5 & 825.2 & 777.6 & 458.1 & 112.2 & 89.7 & 86.2 & 3506.5 \\
\hline & Share, $\%$ & 33 & 23.5 & 22.2 & 13.1 & 3.1 & 2.6 & 2.5 & 100 \\
\hline \multirow[t]{2}{*}{2011} & $\begin{array}{l}\text { Revenues, } \\
\text { LVL million }\end{array}$ & 1295.2 & 958.7 & 792.2 & 481.5 & 196.4 & 110.2 & 112.5 & 3946.7 \\
\hline & Share, $\%$ & 32.8 & 24.3 & 20.1 & 12.2 & 4.9 & 2.8 & 2.9 & 100 \\
\hline \multicolumn{2}{|c|}{$\begin{array}{l}\text { Changes } 2011 / 2008, \\
\text { LVL million }\end{array}$} & -372.3 & -158.5 & -243.2 & -59.4 & -306.7 & 39.5 & 37.8 & -1062.8 \\
\hline
\end{tabular}

Explanation. SSIMC - State social mandatory insurance contributions; VAT - Value added tax; PIT - Personal income tax; LTG - Lottery and gambling tax; CIT - Corporate income tax; IPT - Immovable property tax.

Source: based on Par tautsaimniecības attīstību ... (2008), LR Finanšu ministrija (2011), Kopsavilkums par budžeta ieņēmumu ... (2011, 2012). 
increase in the tax rate from $23 \%$ to $26 \%$ ) and 2011 (reduction in the tax rate from $26 \%$ to $25 \%$ ), the growth of personal income tax was relatively small, and in 2011 it amounted to LVL 792.2 million, which is by LVL 243.2 million or $23.5 \%$ less compared with 2008. Similarly, the increase in state social mandatory insurance contributions in 2011 (the employee rate was increased from $9 \%$ to $11 \%$, thus increasing the total rate from $33.09 \%$ to $35.09 \%$ ) ensured the collection of only LVL 137.7 million or $11.9 \%$ compared with 2010 (Kopsavilkums par budžeta ..., 2011).

In 2011, revenues from value added tax decreased by LVL 158.5 million or $14.2 \%$ compared with 2008. The decline occurred irrespective of the tax rate increase in 2009 (from the previous $18 \%$ to $21 \%$ ) and in 2011 (from $21 \%$ to $22 \%$ ). The decrease in value added tax relates to the decline in retail turnover, and decrease in economic activity and import volume.

In 2011, a slight increase in total tax revenues by LVL 440.2 million or $12.6 \%$ compared with 2010 was experienced after the significant decline in tax revenues in 2009 and 2010.

In 2011, total tax revenues fell down by LVL 1062.8 million or $21.2 \%$ compared with 2008 ; only revenues from immovable property tax have grew by LVL 39.5 million or $35.8 \%$ compared with 2008.

According to Table 2, revenues from immovable property tax have had an annual increasing tendency in absolute figures. A decline in revenues from immovable property tax in absolute figures was observed only in 2008. The change in immovable property tax rate for land from $1.5 \%$ to $1 \%$ of cadastral value and the introduction of limitation for the increase in tax in the amount of $25 \%$ explain the decrease in revenues from immovable property tax. An essential increase in the share of immovable property tax in general tax revenues of Latvia is experienced starting from 2010 with the increase in immovable property tax rate for land (to $1.5 \%$ instead of a $1 \%$ rate set earlier) and expansion of the set of items taxable with immovable property tax. Starting from 2011, the immovable property tax is levied upon engineering constructions (a tax rate of $1.5 \%$ ) and residential buildings (a tax rate of $0.1-$ $0.3 \%$ ). In 2011, the tax rate for residential buildings was doubled to $0.2-0.6 \%$, thus also increasing the revenues from immovable property tax and reaching the highest indicator of LVL 110.2 million in 2011 (Kopsavilkums par budžeta ..., 2011).
The analysis of position of each tax in total tax revenues of Latvia shows that in 2011, the state social insurance mandatory contributions constituted the largest share or $32.8 \%$ of tax revenues followed by value added tax $-24.3 \%$, personal income tax $19.83 \%$, excise tax $-12.2 \%$, corporate income tax $4.9 \%$, and immovable property tax $-2.8 \%$. Hence, the five largest taxes in terms of revenues were as follows: state social insurance mandatory contributions, value added tax, personal income tax, excise tax, and corporate income tax. The immovable property tax took the 6th position and its share in tax revenues of 2011 was relatively small $-2.8 \%$; however, its share had increased by 1.4 percentage points compared with 2008. The growth of immovable property tax share relates with the increase in immovable property tax in absolute figures and the changes in the structure of other taxes (corporate income tax, personal income tax, value added tax, etc.) - the decrease in revenues and share in total tax revenues, thus simultaneously causing the increase in immovable property tax share.

Further, the authors have analysed the breakdown of revenues from immovable property tax in the largest cities/towns and counties of Latvia in 2011 (Fig. 1), since the immovable property tax takes an essential position in a municipal budget and is the only tax which is paid to the municipal budget for $100 \%$.

As shown in Figure 1, in 2011, the largest share of immovable property tax amount has been collected in Riga city, namely, $53 \%$ of total tax revenues, while the smallest share, $0.4 \%$, goes to Jēkabpils town; totally $32.9 \%$ were collected in 109 counties (LR Finanšu ministrija, 2011). These data allow concluding that the immovable property tax takes a significant position exactly in the municipality of Riga city, since the revenues from immovable property tax constitute more than a half of the total revenues from immovable property tax collected in Latvia.

These large differences in the share of immovable property tax among cities and towns coincide with the difference in cadastral values, since the cadastral value is the base for calculation of immovable property tax. Therefore, the authors proceed with the analysis of the amounts of cadastral values for land and buildings determined by the State Land Service in cities and towns of Latvia for 2011 (Tables 3 and 4). According to the data summarised in Table 3, the biggest cadastral value for land among the largest cities of Latvia is observed in Riga 


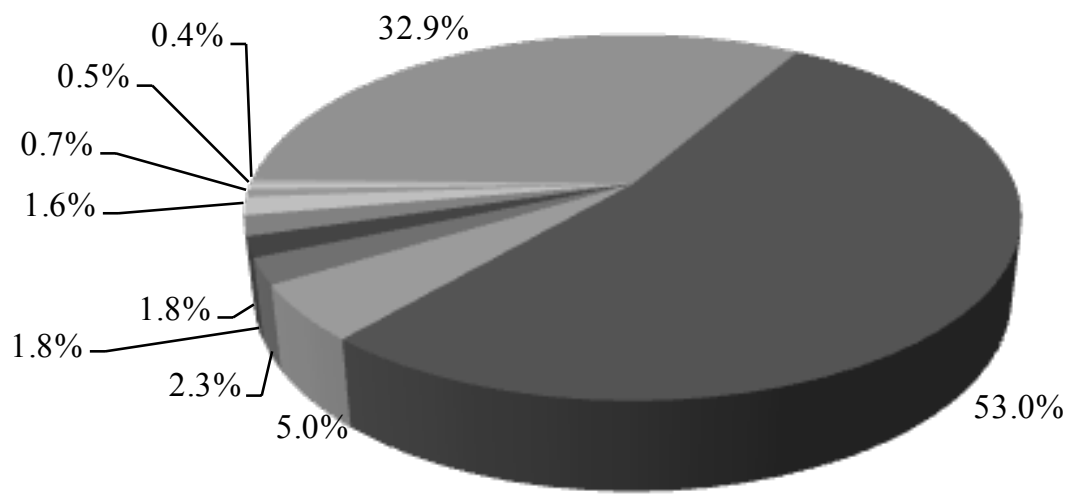

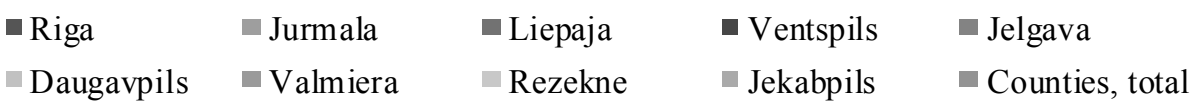

Source: calculations based on LR Finanšu ministrija (2011).

Fig. 1. Breakdown of revenues from immovable property tax by cities/towns and counties of Latvia in 2011, \%.

Areas of land units and cadastral values in the largest cities and towns of Latvia in 2011

\begin{tabular}{lcc}
\hline Cities/Towns & $\begin{array}{c}\text { Total area of land units, } \\
\text { ha }\end{array}$ & $\begin{array}{c}\text { Total amount of cadastral values of land units, } \\
\text { LVL million }\end{array}$ \\
\hline Riga & 28840.24 & 3054.43 \\
\hline Daugavpils & 7237.89 & 60.85 \\
\hline Jelgava & 6040.83 & 103.03 \\
\hline Jēkabpils & 2550.41 & 21.74 \\
\hline Jürmala & 9859.69 & 518.73 \\
\hline Liepāja & 6766.81 & 263.94 \\
\hline Rēzekne & 1748.18 & 25.62 \\
\hline Valmiera & 1813.39 & 36.49 \\
\hline Ventspils & 5729.78 & 115.21 \\
\hline
\end{tabular}

Source: based on Zemes un ēku kadastrālās ... (2012).

Table 4

Number of buildings and cadastral values in the largest cities and towns of Latvia in 2011

\begin{tabular}{lcc}
\hline Cities/Towns & Number of buildings & Total amount of cadastral values, LVL million \\
\hline Riga & 108909 & 6533.33 \\
\hline Daugavpils & 46999 & 300.26 \\
\hline Jelgava & 19168 & 346.05 \\
\hline Jēkabpils & 11716 & 67.75 \\
\hline Jūrmala & 25921 & 581.84 \\
\hline Liepāja & 17830 & 401.92 \\
\hline Rēzekne & 12739 & 88.31 \\
\hline Valmiera & 7520 & 140.75 \\
\hline Ventspils & 18273 & 247.56 \\
\hline
\end{tabular}

Source: based on Zemes un ēku kadastrālās ... (2012). 
(LVL 305.44 million), which respectively presents the largest total area of land units (28840.24 ha). Riga is followed by Jūrmala, Liepāja, Ventspils, Jelgava, Daugavpils, Valmiera, Rēzekne, and Jēkabpils by the amount of cadastral values for land (by the share of immovable property tax as well). However, cities and towns are grouped differently by the area of land units, namely, Riga is followed by Jūrmala, Daugavpils, Liepāja, Jelgava, Ventspils, Jēkabpils, Valmiera, and Rēzekne (Zemes un ēku ..., 2012).

According to the information of Table 4, Riga city has the largest cadastral value for buildings (LVL 6533.33 million), which respectively also presents the largest number of buildings (108 909). Riga city is followed by Jūrmala, Liepāja, Jelgava, Daugavpils, Ventspils, Valmiera, Rēzekne, and Jēkabpils by the amount of cadastral values for buildings. Yet, Riga is followed by Daugavpils, Jūrmala, Jelgava, Ventspils, Liepāja, Rēzekne, Jēkabpils, and Valmiera by the number of buildings. The analysed information leads to the conclusion that the total area of land units and number of buildings in cities/towns do not affect the amount of cadastral value and simultaneously the amount of immovable property tax (Zemes un èku ..., 2012).
The base of cadastral value is the main factor affecting the amount of cadastral value. The base of cadastral value is adopted by the Cabinet by 15 June of each year. The base of cadastral value is a set of data characterising values necessary for the calculation of cadastral value - base values and adjustment ratios. These values and ratios are determined for a group of cadastre items in a relatively homogeneous territory, zone, in terms of values; the determination is based on the analysis (two previous years are considered) of real estate market information (Nekustamā īpašuma valsts..., 2005).

\section{Analysis of revenues from immovable property tax collected in Riga city}

Personal income tax, immovable property tax, and lottery and gambling tax constitute the main revenues in the budget of Riga City municipality.

Tax revenues of the Riga city general budget for the period of 2006-2011 is shown in Table 5. Its data analysis reveals that in 2011, total tax revenues decreased by LVL 88.2 million or $22.3 \%$ compared with 2008. The slowdown of economic activity in the country promoted the decrease in the amount of tax revenues - increase in unemployment and reduction in work payment (Rīgas pilsētas pašvaldības...,

Tax revenues of Riga City for the period of 2006-2011

Table 5

\begin{tabular}{|c|c|c|c|c|c|c|c|}
\hline \multirow{2}{*}{ Year } & \multirow{2}{*}{ Indicator } & \multirow{2}{*}{ PIT } & \multicolumn{3}{|c|}{ IPT } & \multirow{2}{*}{ LTG } & \multirow{2}{*}{$\begin{array}{c}\text { Tax } \\
\text { revenues, } \\
\text { total }\end{array}$} \\
\hline & & & total & on land & on buildings & & \\
\hline \multirow{2}{*}{2006} & Revenues, LVL million & 214.0 & 31.0 & 10.1 & 20.9 & 3.3 & 248.3 \\
\hline & Share, $\%$ & 86.2 & 12.5 & 4.1 & 8.4 & 1.3 & 100.0 \\
\hline \multirow{2}{*}{2007} & Revenues, LVL million & 300.3 & 40.3 & 10.1 & 30.1 & 4.6 & 345.2 \\
\hline & Share, $\%$ & 87.0 & 11.7 & 2.9 & 8.8 & 1.3 & 100.0 \\
\hline \multirow{2}{*}{2008} & Revenues, LVL million & 351.9 & 38.4 & 14.2 & 24.2 & 4.4 & 394.7 \\
\hline & Share, $\%$ & 89.2 & 9.7 & 3.6 & 6.1 & 1.1 & 100.0 \\
\hline \multirow{2}{*}{2009} & Revenues, LVL million & 258.9 & 38.6 & 16.4 & 22.2 & 3 & 300.6 \\
\hline & Share, $\%$ & 86.1 & 12.9 & 5.5 & 7.4 & 1 & 100.0 \\
\hline \multirow{2}{*}{2010} & Revenues, LVL million & 261.0 & 45.9 & 19.1 & 26.7 & 2.4 & 309.3 \\
\hline & Share, $\%$ & 84.4 & 14.8 & 6.2 & 8.6 & 0.8 & 100.0 \\
\hline \multirow{2}{*}{2011} & Revenues, LVL million & 245.8 & 58.4 & 26.3 & 32.1 & 2.3 & 306.5 \\
\hline & Share, $\%$ & 80.2 & 19.1 & 8.6 & 10.5 & 0.7 & 100.0 \\
\hline \multicolumn{2}{|c|}{$\begin{array}{l}\text { Changes } 2011 / 2008, \\
\text { LVL million }\end{array}$} & -106.1 & 20.0 & 12.1 & 7.9 & -2.1 & -88.2 \\
\hline
\end{tabular}

Explanation. PIT - Personal income tax; IPT - Immovable property tax; LTG - Lottery and gambling tax.

Source: based on Rīgas pilsētas pašvaldības ... (2011), LR Finanšu ministrija (2011), Unpublished data of the Immovable Property Tax Administration Program of Riga City Council for the period of 2006-2011. 
2010, 2011). Revenues from immovable property tax were the only revenues that had increased by LVL 20 million or $52.1 \%$ in 2011 compared with 2008. Therefore, the authors will further analyse the changes in the tax revenues from immovable property tax and tax share in the budget of Riga City municipality.

According to Table 5, the share of immovable property tax declined from $12.5 \%$ to $9.7 \%$ for the period of 2006-2008, but for 2009-2011, on contrary, it annually increased constituting 19.1\% in 2011. Also in absolute figures, revenues from the immovable property tax produce an annual increasing tendency.

Analysing the increase in immovable property tax individually by land and buildings, it may be concluded that growth tendencies were different. As shown in Table 5, the immovable property tax for buildings increased until 2008; a significant increase was observed in 2007. The increase is associated with the changes in immovable property tax base for buildings. Starting from 2007, the tax for buildings is calculated from the cadastral value of buildings, while previously, it was calculated from the book value of buildings, which was reduced due to depreciation. At the same time, cadastral values for buildings were determined for tax needs upon updated value bases.

The immovable property tax for buildings declined in 2008 and 2009, which is related with the change in calculation procedure of cadastral value for production units. The calculation of cadastral value for 2007 was based on the volume or cubic metres of production unit, but for the year 2008 - on the total area of building in square metres.

In 2007, revenues collected from the immovable property tax for land stayed on the level of 2006; however, a rapid increase in immovable property tax was observed from 2008. The increase is related with updating of cadastral base value for land in 2007, which influenced the amount of immovable property tax.

The analysed data (Table 5) allow concluding that the increase in the second most important source of revenues - immovable property tax - in Riga municipality from 2010 is explained by the fact that the immovable property tax is imposed upon residential buildings and engineering constructions starting from 2010, thus causing the strengthening of this tax and growth of its share in total tax revenues of Riga municipality.

\section{Conclusions}

1. Immovable property tax is one of the national taxes the administration of which is subjected to continuous changes. Frequent amendments to the law "On Immovable Property Tax" also evidence the mentioned changes.

2. Not only the enumeration of taxable items but also the procedure for tax calculation, tax base, and tax rates has been considerably changed for the period of 1998-2012.

3. Starting from 2013, the government of Latvia has envisaged considerable changes in the sphere of immovable property tax. It is anticipated to confer the rights to the municipalities to determine immovable property tax rates within a range from $0.2 \%$ to $3 \%$.

4. Starting from 2013, municipalities will have to observe several principles setting the immovable property tax rates: principle of equitable grouping, principle of efficiency, principle of responsible budget planning, principle of predictability and stability, principle of business support, principle of social responsibility, and principle of territorial development.

5. The analysis of tax revenues and tax structure in Latvia for the period of 2008-2011 shows that in 2011, total tax revenues have fallen by LVL 1062.8 million or $21.2 \%$ compared with 2008. Only revenues from immovable property tax have grown by LVL 39.5 million or $35.8 \%$ compared with 2008. The increase in immovable property tax rate for land (to $1.5 \%$ instead of a $1 \%$ rate set earlier) in 2010 and expansion of the set of items taxable with immovable property tax (engineering constructions and residential buildings) explain the increase in revenues from immovable property tax and its share.

6. Immovable property tax takes a significant position in tax revenues of Riga City municipality, since the largest share or $53 \%$ of the total amount collected from immovable property tax in 2011 pertains to Riga City municipality.

7. The analysis of tax revenues from immovable property tax in Riga City general budget tax revenues show that revenues from immovable property tax have an annual increasing tendency in absolute figures for the period of 2006- 
2011. Revenues from immovable property tax are the only revenues that have increased by LVL 20 million or $52.1 \%$ in 2011 compared with 2008.

8. The continuous changes in immovable property tax and tax revenues reforms indicate its topicality and significance in the tax system of Latvia. Therefore, it may be asserted that frequent reforms of immovable property tax have promoted the development of a new, stable and predictable methodology for the future application of immovable property tax in Latvia.

\section{References}

1. Aizsilnieks, A. (1968). Latvijas saimniecības vēsture 1914-1945. Stokholma: Daugava.

2. Fiḷipoviča, N., \& Lāce, N. (2006). Nodokḷu administrēšanas funcionālās efektivitātes novērtēšana. Latvijas Universitātes raksti, 696. sējums, 99-111.

3. Grozījumi likumā „Par īpašuma nodokli”: LR likums. (1997). Latvijas Vēstnesis, Nr. 309/310. Retrieved from http://www.likumi. lv/doc.php? $\mathrm{id}=52190 \&$ from $=$ off

4. Grozījumi likumā „Par nekustamā īpašuma nodokli": LR likums. (1999). Latvijas Vēstnesis, Nr. 30/31. Retrieved from http://www.likumi.lv/ doc.php?id=21430

5. Grozījumi likumā „Par nekustamā īpašuma nodokli": LR likums. (2000). Latvijas Vēstnesis, Nr. 448/449. Retrieved from http://www.likumi. lv/doc.php?id=13481

6. Grozījumi likumā „Par nekustamā īpašuma nodokli”: LR likums. (2009). Latvijas Vēstnesis, Nr. 200. Retrieved from http://www.likumi.lv/ doc.php?id=202366

7. Grozījumi likumā „Par nekustamā ìpašuma nodokli": LR likums. (2011). Latvijas Vēstnesis, Nr. 202. Retrieved from http://www.likumi.lv/ doc.php?id=241838

8. Grozījumi likumā „Par zemes nodokli”: LR likums. (1997). Latvijas Vēstnesis, Nr. 155/156. Retrieved from http://www.likumi. lv/doc.php? $\mathrm{id}=51970 \&$ from $=$ off

9. Guḷāns, P. (2010). Nekustamā ìpašuma nodokļa sociāli ekonomiskie aspekti. Retrieved from http://www.lvportals.lv/?menu=doc\&id=222858

10. Informatīvais ziņojums par nekustamā ìpašuma nodokl̦a politikas pilnveidošanu, ar mērksi novērst būtisku nekustamā ìpašuma nodokļa sloga palielināšanu iedzīvotājiem. (2007). Retrieved from www.lps.lv/faili/ Infolapa2007/262007_piel2.doc

11. Kavale, L. (1998). Nodoklı politika. Rīga: Valsts administrācijas skola.

12. Kārtība, kādā tiek piemērots nekustamā īpašuma nodoklis atsevišķiem nekustamā īpašuma nodokla objektiem Ventspils pilsētā 2012. gadā. (2012). Ventspils pilsētas domes saistošie noteikumi Nr. 2. Retrieved from http://www. ventspils.lv/files/dokumenti/pamatin formacijai/ parvalde/publiskiedokumenti/finansunodala/ Saistosie_noteikumi_2.pdf

13. Ketners, K. (2009). Nodokļi Eiropas Savienūbas vidē. Rīga: Banku augstskola.

14. Kodoliṇa-Miglāne, I. (2007). Nodokļi Latvijā 2007. Rīga: Biznesa Augstskola Turība.

15. Kopsavilkums par budžeta ieņēmumu daļas izpildi 2010. gada 12 mēnešos. (2011). Retrieved from http://www.vid.gov.lv/dokumenti/noderigi/ statistika/nodoklu\%20ienemumi/ien_12_2010. pdf

16. Kopsavilkums par budžeta ien̦ēmumu daļas izpildi 2011. gada 12 mēnešos. (2012). Retrieved from http://www.vid.gov.lv/dokumenti/noderigi/ statistika/nodoklu\%20ienemumi/kopsavilkums_ ien_2011g.pdf

17. LR Finanšu ministrija. (2011). Makroekonomikas un budžeta apskats. Retrieved from http://fm.gov.lv/ files/files/4C05 BC220873001328083638827981

18. LR Finanšu ministrija. (2012). Likumprojekta „,Grozījumi likumā „Par nekustamā ìpašuma nodokli"," sākotnējās ietekmes novērtējuma ziņojums: anotācija. Retrieved from www. mk.gov.lv/doc/ 2005/FManot_150312_ NIN_2013.303.doc

19. Lukašina, O. (2004). Nodokļi Latvijā: analīze un praktiskie ieteikumi. Rīga: Merkūrijs.

20. Nekustamā īpašuma nodokļa piemērošanu Jelgavas pilsētas administratīvajā teritorijā. (2012). Jelgavas pilsētas pašvaldības saistošie noteikumi Nr. 12-1. Retrieved from www. likumi.lv/doc.php?id=242719\&from $=$ off

21. Nekustamā īpašuma valsts kadastra likums: LR likums. (2005). Latvijas Vēstnesis, Nr. 205. Retrieved from http://www.likumi.lv/doc. php?id $=124247$

22. Par īpašuma nodokli: LR likums. (1990). Ziņotājs, Nr. 3. Retrieved from http://www. likumi.lv/ doc.php?id=64873 
23. Par nekustamā ìpašuma nodokli Jūrmalā 2012. gadā. (2012). Jūrmalas pilsētas domes saistošie noteikumi Nr. 2. Retrieved from http:// www.likumi.lv/doc.php?id $=243699 \&$ from $=$ off

24. Par nekustamā ìpašuma nodokli: LR likums. (1997). Latvijas Vēstnesis, Nr. 145/147. Retrieved from http://www.likumi.lv/doc. php?id=43913

25. Par nekustamā īpašuma nodokli Rīgā 2012. gadā. (2012). Rīgas domes saistošie noteikumi Nr. 161. Retrieved from www.likumi.lv/tv_faili.php?doc_ $\mathrm{id}=243054 \&$ get_file_id $=17204$

26. Par nekustamā ìpašuma nodokla aprēķināšanu 2012. gadā. (2012). Liepājas pilsētas domes saistošie noteikumi Nr. 1. Retrieved from www.likumi.lv/doc.php?id=243405

27. Par nekustamā īpašuma nodokļa piemērošanu Daugavpils pilsētas administratīvajā teritorijā. (2012). Daugavpils pilsētas domes saistošie noteikumi Nr. 5. Retrieved from http://www.likumi.lv/doc.php?id=243712

28. Par pašvaldībām: LR likums. (2011). Latvijas Vēstnesis, Nr. 201. Retrieved from http://www.likumi.lv/doc.php?id=57255

29. Par tautsaimniecības attīstību un kopbudžeta izpildes gaitu 2007. gadā. (2008). Retrieved from http://www.fm.gov.lv/files/files/2007_IV.pdf

30. Par zemes nodokli: LR likums. (1990). Ziņotājs, Nr. 11. Retrieved from http://www.likumi.lv/ doc.php?id $=64972$
31. Rīgas pilsētas pašvaldības 2011. gada pamatbudžeta ieņēmumi un izdevumi. (2011). Retrieved from http://riga.lv/media/ budzets/2011/2grozijumi/03_Pielikums_2_ Nr.145.pdf

32. Rīgas pilsētas pašvaldības publiskais pārskats. (2010). Retrieved from http://riga.lv/NR/ rdonlyres/ B6734810-A3C0-40BF-866CD0205CBA0079/34690/RD_Parskats_2010.pdf

33. Sīpola, E. (2001). Mūsdienu nodokļu teorija. Rīga: RTU.

34. Sproǵe, I. (2007). Latvijas nodokḷu politikas attīstības iespējas. Tautsaimniecības attīstības problēmas Latvijā, Nr. 5, 160-171.

35. Urtāns, A. (2003). Nodoklu un nodevu vēsture Latvijā. Rīga: SIA Premo.

36. Vanags, J. (2010). Nekustamā ipašuma ekonomika. Rīga: RTU.

37. Vītola, $\bar{I}$. (2006). Nekustamā īpašuma nodoklis Latvijā: tā uzskaites problemātiskie aspekti un pilnveidošanas iespējas. Tautsaimniecības un uzñēmējdarbības attīstības problēmas: RTU 47. starptautiskās zinātniskās konferences referāta tēzes (85-86 lpp). Rīga: RTU.

38. Zemes un èku kadastrālās vērtības 2011. gadā valsts administratīvo teritoriju griezumā. (2012). Retrieved from http:/www.vzd.gov.lv/sakums/ publikacijas-un-statistika/statistika-par-vzdregistros-uzkrato-informaciju/?id=805

39. Zvejnieks, A. (2006). İpašums un nodokļi. Rīga: RTU. 